\title{
Little Friends of Halide Nusret Zorlutuna and Teaching Profession*
}

\author{
Fatma Süreyya Kurtoğlu
}

Faculty of Arts, Gazi University, Turkey

Copyright $\mathrm{C} 2018$ by authors, all rights reserved. Authors agree that this article remains permanently open access under the terms of the Creative Commons Attribution License 4.0 International License

\begin{abstract}
In rapidly growing world, the modern civilizations' efforts to make their citizens are always vital. The societies which have well-educated manpower naturally have a right to rule the world. Teacher qualifications that constitute the base of the education system will surely denote the quality of the education system. The teachers are the ones who need to be a guide to make students reach the information and to use that information. Constructing standardizations for teaching profession, generating national and universal policies about this profession which is an important job as it includes teaching should be the primary goal for the nations that wish to develop. Between 1924 and 1957, Halide Nusret Zorlutuna who worked as a teacher in diverse cities situated in newly founded Turkish Republic contributed to our country's need for well-educated manpower as an educator. Later on, Zorlutuna published her observations while she was working as a teacher with a little memory book called "Benim Küçük Dostlarım". This memory book was not only about life, country and environment, but also included a great deal of clues about teaching profession. This study was carried out in order to determine Halide Nusret Zorlutuna's thoughts and practices about teaching profession. Data were collected via document analysis method. The source of data of the study is "Benim Küçük Dostlarım". Descriptive analysis method was employed to analyze the data. In the present study, the thought and applications of the teaching profession between the lines of Halide Nusret Zorlutuna's memory book called "Benim Küçük Dostlarım" were determined and an evaluation was put forward. Accordingly, teachers should love students and make students love them, be fair for all students, guide them for good and bad, encourage them and they should not be afraid of any troubles, give up hope and should continue teach event the weakest student with patience, seek for new solutions in teaching, establish a relationship with students' parents to achieve success which they are one of the most important shareholders in the education, remember teaching is firstly self-sacrifice and most importantly they should be model for students in all respects.
\end{abstract}

Keywords Turkish Language and Literature, Halide Nusret Zorlutuna, Teaching Profession

\section{Introduction}

In the world developing dizzyingly and having needs changing at least at that speed, there is a great need for qualified work force which can keep up with and direct that reality of the world. One of the primary purposes of the education is to raise individuals who fit into society and support the society by their knowledge and skills.

In general, education defined as "the process to raise people by certain purposes" [1] is a system in which every society specifies strongly policies for the future in terms of raising qualified person. Teachers are one of the most important factors in this system.

In Article 43 of National Education Fundamental Law, it is defined that "Teaching profession is a special expertise profession that undertakes education and teaching and the relevant management duties of the state." [2]

Teachers are obliged to fulfill their duties in accordance with purposes and basic principles of Turkish National Education. Again, in accordance with Fundamental Law, they should have certain positive personal qualities, liberal education and field knowledge as well as teaching function. Education programs are applied for training teachers suitable for these qualifications in the faculties of education at the universities which are entrusted with training teachers.

In general, teachers are supposed to have certain qualities to teach more efficiently as well as certain qualifications such like liberal education and field knowledge as mentioned above. An effective teacher is patient and strong against some events; they can control their feelings; they take care of their appearance, hygiene and order; they are open to self-development and criticism; they don't engage the class and school in their own problems; they don't have characteristics motivating the 
students; they focus on the success; they are a role model for the students by their ideas and behaviors; they are good-humored, tolerant and affectionate to the students; they are reliable, honest, objective, confidant and friend for the students; they create a constructive and educational discipline in the class; they have leading characteristics; they are successful at influencing students, parents and the environment; they have characteristics of mediation, arbitration, representation; they are encouraging and supportive, merciful, understanding and witty; they make effort to solve the problems instead of complaining and establish the authority in the class; they follow and control the homework given; they known basic concepts of educational sciences and make learning easier; they are good observers and always make effort to renew themselves [3].

In this regard, teaching is not a profession that anyone can do instead a profession of healthy personality and character. It is nothing but underestimating teaching profession to think that those who don't perceive themselves as teachers and those who think that teaching is not a suitable profession for themselves will be good teachers $[4,5]$.

As well as the qualifications which all teachers should have, there are some other qualifications required by every branch. In this context, Turkish Philosophy teachers should be interested in Turkish language, history, literature and culture and also have consciousness of national history. Only teachers who have this consciousness both make students successful in academic sense and help them to get an idea of life and the future along with national and moral values.

There are a wide range of works which are based on teaching profession in Turkish literature, problems can be encountered by the teachers and how this profession should be. Heroes, who had tried to continue this profession in great difficulties especially during national struggle and in the first years of Republic, were the subject of other literary genres particularly narration works.

Teachers undertook important functions to introduce people with innovations made to ensure development in social sphere after establishment of the Republic and install them permanently. Representatives of this profession group leaving their comfortable lives in Istanbul moved to Anatolia and took important tasks to introduce human profile required by new Republic. Works indicating what the role of women should be especially in this new social life are pretty important in this regard. Women characters are teachers in the novels Çalıkuşu (1922) and Acımak (1928) by Reşat Nuri Gültekin and Vurun Kahpeye (1926) by Halide Edip Advvar, and they are remarkable names by their statuses and struggles in the social life of that period.

Erdal's study evaluating the teaching profession by drawing from literary works draws attention in the literature survey. In this study, the researcher, in general, gave a consideration to views on education and teaching of
Halide Edip Adıvar and Halide Nusret Zorlutuna [4]. Another study belongs to Şanal. Şanal also referred to the views of Halide Edib Adıvar, who is best known for his literary and writer identity, in his work regarding the teaching profession and the teaching profession [15]. Teacher metaphors in Çalıkuşu novel were determined in the work of Atıcı and Yaylı [16]. In the study of Yilmaz, while discussing the female teacher typologies in Turkish literature, the "Professional Personalities" of teacher typologies in selected novels were discussed; and how these can be shed light on the work that is currently being done and planned to be done in this area [17]. In the graduate study by Aydın, there are evaluations about types of teachers in the novels of Reşat Nuri Güntekin and their dimensions about how they are perceived by the society [18]. In the study of Emek, the Turkish and literary teaching character, which is included in twenty-six stories written from the Tanzimat period to the present day, was examined in terms of educational values [19].

Note that most of the work undertaken is based on the views and practices of the fictional heroes in the texts regarding the teaching profession. Our work is aimed at identifying and evaluating the views and practices of a writer about his/ her profession.

The work called Benim Küçük Dostlarım (My Little Friends) written by Halide Nusret Zorlutuna, who is subject of our study, is actually summary of the life and determination of a woman teacher who struggles with poverty on one hand and ignorance on the other hand in a country that has struggled for independence recently.

Halide Nusret, who lived in 1901 to 1984, was daughter of Mr. Mehmet Selim, one of the journalists at period of Abdülhamit II became famous by his struggle of independence [6]. She took different lessons from private teachers in Kirkük where they lived due to her father's job, completed her education in Istanbul and she was appointed as teacher to Edirne Teaching School for Girls in 1924. She was retired voluntarily in 1957 while she was literature teacher at Technical Teaching School for Girls. The author who also participated in some organizations to strengthen women in social sense was presented with various titles and service certificates in these respects. Zorlutuna, who died in 1984, was interested in literature at tender ages and composed a wide range of works such as novels, memory, story and poems as well as teaching profession $[7,8]$.

\section{Method}

In the study, document analysis technique was used as qualitative research methods as data collection tool. Document analysis is seen as a data collection method that can be used as a data collection tool alone, consisting of an analysis of written materials containing information about the targeted cases to be searched by the researchers [13]. Karasar (2010) states that the method of document analysis 
can also be named as "documentary observation", "systematic examination of existing records or documents as data sources", "document scanning" and "library research" [14].

For the analysis of the obtained data, a descriptive analysis method was used. The data obtained in the descriptive analysis are summarized and interpreted according to the previously determined theme. In this type of analysis, the aim is to present the findings to the reader in an organized and interpreted way [13]. In descriptive analysis, direct quotations made from verbs that are subject to research are frequently given. In this context, the results obtained as a result of descriptive analysis are presented in a descriptive way, and the findings and findings of the author in the book are quoted in the same way and the findings are formed.

\section{Results}

In her work called "My Little Friends" written as memory type, Halide Nusret Zorlutuna tells about teaching profession she performed with love by considering it as a divine goal, her dear students from whom she learned a lot and her teaching memories which she assumed memorable. The book presents easily remembered sweet memories in the course of teaching profession while it demonstrates specifics of teaching profession as well as political, economic, social conditions of that period. Language and literary style used to present these determinations are remarkable.

Fevziye Abdullah Tansel makes the evaluation that "Inspired, short stories about the teaching memories" for the work "My Little Friends" while Arif Nihat Asya, one of the important names in Turkish literature states that "I recommend it to the relevant persons not only as a memory but also a professional book...I think it is a book that should be included in school classics. I insist on and persist in my thought. This book is one of the books which the education looks for and supposes that there is no such a book." for this work of Zorlutuna [8].

The author, who had an intellectual family believed necessity of the education in those days, presented her book called "My Little Friends" to Ahmet Halit Yaşaroğlu, her elder brother for whom she told "he always got pleasure to carry teaching profession such as a crown of honor at the beginning of his name" [7].

"It is the most prominent feature of this work that the author expresses the impression of teaching effectively." [7]. Halide Nusret Zorlutuna, who performed teaching profession actually in several educational institutions in many cities between the years of 1924 and 1957, states the reason for choosing this profession at the preface of her book that:

"I love children too much. Every person has a weak point, fond in the life. My single and biggest weakness is - why not we admit...- love of children! And this is why I attached to teaching profession such as a propeller rotating around the light because of this love.

I love not only lovely, urbane, clever and hardworking ones - everybody can love anyone like this- but also unlovely, glum, even stupid children. The voice calling me as "Teacher!" is lovely and valuable for me like a voice calling me as "Mom!"

Every child is a book that is worth to be read and curious from one to twenty ages and the world of mysteries to think about for a long time and with admiration.

I have been trying to read and understand these books page by page and line by line for twenty years. But it is true that "I still encounter some statements which I can't understand and interpret in this book called "Child" [9].

As in all professions, the essential condition in teaching is to love the profession and endear themselves to students. Teachers should primarily love their profession and make students feel that their teacher loves and appreciate them. Students who feel they are loved and appreciated can follow their teacher and achieve success easily.

Halide Nusret includes these lines in her book concerning this subject:

"Children - especially little girls" love young teachers. If an old teacher can make students love them and their lessons, this is because of their knowledge filtered through experiences of long years and measured, planned actions. Or because of superior love and compassion overflowing such like a flood of lights. But young teacher - if she/he is a little lovely and smiling clever- she/he can make students love her/him easily despite al inexperience, awkwardness. Sometimes, a smiling of her/his living eyes, bending her/his shiny head can fascinate all the class. And then "the victory" belongs to him. Spirits of all children wait for the teacher to pick them and spread seeds as if they are an uncultivated rich soil at his elbow." [9].

Teaching profession is the leading profession from which a feedback can be received over the time. It is always possible to see the student, to which you've made effort, as a helpful individual for other people over the time. In this respect, it is one of the professions you can feel the highest moral pleasure. Any effort made would not go down the drain. The author, who came up against severely people who regard teaching profession as "an ungrateful profession", talks about the satisfaction people feel by this profession which she venerates in her book:

"My little friends... But most of them are not little any more. They have distributed as teachers, military officers, doctors, judges, lawyers, officers or artists - 
even there is a queen among them!... They have distributed across the country. And thank God, most of them are mothers and fathers today.

Whenever I arrive in a city, a town of Anatolia, $l$ encounter a young woman or man who kisses my hands saying 'My teacher' and then my heart flies by hugging silk wings of the satisfaction.

People who regard my profession as ungrateful are really wrong. You can't feel this unique feeling by any profession apart from "teaching" [9].

"For several years now, it was a feast day, dear Dr. Vecihe Danışoğlu, one of the oldest ones of my little friends, visited me with almost ten of her school mates. A handful of dear people of "gold youth of the east...

Little children were not "little", even "young"; even I didn't know some of them; when they said their names, I crowed saying "Ohh, are you my little kiddy? What a beautiful feast day, like a multiple roses!

I talked about my pleasure, honor of seeing My Little Friends as being mothers and fathers in my first "Preface". And in this feast day, I saw them as "grandmothers" and "grandfathers"; even lady "grandmothers" and gentleman "grandfathers".

Honorable, real people who performed and have been performing their duties for their countries...

“Lucky me! Thanks be to God!” [9].

Teachers establish a future for their society through the new generation they trained. Teachers raise workforce such like doctors, engineers, policemen, drivers, etc. who provide services at all levels of society. They shape in details characters of these individuals they trained. One of the essential conditions is to dream what you want to make real. Teachers should primarily be able to imagine what a generation they will raise. These dreams would set a course for making these dreams come true. Halide Nusret often imagines the point to reach for her profession. Even, she makes it a game. After giving homework to her students in her classes, she starts dreaming and tells as the following:

"There was a silence in the class. Children were pretty busy while writing.

I came and went up to the rostrum, sat on the chair and started my ordinary game:

This is a very enjoyable fantasy game; I imagine what kind of a person every child would be in the future; I see them at twenty or thirty ages...

This demure brown-haired child sitting on the front desk; will definitely be an admirable governor. A governor works in a correct and proper manner without paying regard to feeling of others and allowing even a smallest bad work.
Blond child with a thin face sitting behind that child should be a musician or an artist with his long and meaningful fingers. He has both shy and proud eyes becoming to an artist; he is tall with his head high" [9].

While one of the purposes of the schools that are educational institutions is to raise students who can reach level of modern civilizations and even have academic success to go beyond this level, another purpose is to raise good individuals. It is required to teach and make them experience all national, moral, universal values in order to raise a good citizenship, good child, good man, in brief, a good person.

Values education has become more important in recent years and many studies have been begun in this regard. Values intended to be brought in students are presented between the lines of National Education Basic Law and they are included in curriculums of several classes as lists. Zorlutuna makes effort and shows determination to bring students in the values mentioned above even in that years she was performing this profession. In this regard, she knows that primarily she should be a role model. Values for which adults should be model are important factors in education. Students are interested in educators who want to perform something positive and experience the values they approved in their own lives. If there is a conflict between the educators and what they do, students are in tendency to refuse values education." [10].

Halide Nusret, who wants students don't lie and are honest, feels that she should always be honest with them and does so. In the courses, she uses literary works as a method to tell them what is good, beautiful and correct. The following verses of İbrahim Alaattin which she selected to be written by the students in calligraphy lesson are a good example on this subject:

"May be there is a time involved in the darkness,

What disappoints the spirits are trick and lie,

Truth is the sun to come up, believe it!

Is it possible morning would not come after the nights?..." [9].

Again, while she says "Turkish children don't tell lie" to the student she realized that she tells lies [9] and so makes the student feel sorry for what she did in the context of bringing them in national and moral values, the following lines are remarkable in which she almost begs her student by asking her to not lie in order to bring them in the same value:

"Neriman, tell me the truth please, I won't give you hard feelings, any punishment; even, I will help you. But, tell me the truth please! Do not lie to me, do not lie!... [9].

Zorlutuna, who wants to bring students in a value such as sedulity, raises pleasure of being successful by studying just as she helps a student to pass almost most of the classes 
by encouraging the student, whom everybody sacrificed, by telling "I said do not be disappointed, study. Study! Who studies always wins. Repeat it always by yourself: who studies always wins!" [9].

Teacher should be convincing and that's why she should keep all promises made. This attitude is one of the essential conditions to discipline the school, make students love and believe her, make students to internalize value of honesty.

Zorlutuna, who was loved by students and could establish the authority on the students by means of this convincing virtue of being honest in the years she was manager, mentions this condition in her book as the following:

"I was so-called deputy manager but I didn't understand administration works, enrollment or something like that, records or syllabus. Manager maintained all these works. I was occupied only with discipline at school. My manager assured that my authority was pretty effective and beneficent on young girls; and I focused on my work with all my excitement, body and soul...

I was something more than a teacher, a director for those girls; I was a sincere friend and "sister" they can count on.

To be honest, I made great effort to reach this status. Actually, I was nothing short of an inexperienced and highly fool young girl. But somehow, I don't know, I noticed that they - not all of them but most of themloved me suddenly.

They believed me." [9].

From time to time, training programs and policies conflicting with the facts of country and world, lack of physical infrastructures of the schools, mistakes in training teachers may hinder teachers from conducting properly their educational activities at the classes. But, yet teachers should undertake a constructive, solution generating function to overcome all kind of difficulties in educational activities.

Halide Nusret, who started teaching in a period when people were nationally under a congested, dark and depressed condition in her own words, is an idealist person made effort to perform her profession fearlessly and as it should be within the impossibilities of that period.

Zorlutuna endeavors with a great sense of mission in order that educational activities do not go wrong in those years of impossibilities and invents something in direction of the belief that education should be conducted in a disciplined sense. The author, who felt there was a need for student recognition files prepared specific to each student in order to recognize the students and follow their developments, tells the efforts as the following which she made to fill this deficiency in the section called "Mefharet and her friends":
"At that time, there was no "marks book for the teachers" as it is now. But I invented an unusual book by myself:

It was $15 \times 20 \mathrm{~cm}$ and with hundred pages. I allocated six pages to each student. At first I recorded student's name, father's name, date of birth and described the student. Then, I wrote what I learned about the family - as much as I learned-and I focused on souls of the children; I tried to learn about their inner worlds with a an endless "fire to know, see, learn" into my young, inexperienced, ignorant eyes, and I wrote delicately what I could catch every week in short statements on those pages. I wrote their marks they got in the classes on the last page of every section I allocated to each student." [9].

Every student is a different world waiting for being discovered and filled with treasures. A good teacher should recognize characteristics and living conditions of the students and determine a specific method and be able to make students feel how much they are valuable for their teachers. Zorlutuna prepared a teacher's book of marks in the conditions of that period. Expressions, which she used in this book while telling about a student called "Mefharet", show how much she cared about generally people and privately students whom she called "my children" and also her belief that she should know them well in order to provide a good education.

Especially Turkish and Turkish Philology teachers should be able to have an aesthetics pleasure and contribute formation of this aesthetics pleasure for their students. While knowledge of language and literature is transferred, students should be encountered with good examples of this language. Halide Nusret is a name known by her actress identity as is known. Language and style used by Zorlutuna, who described nature, events and individuals in a very living sense in her books and created literary works with colorful words and statements with many metaphors, in the section of the marks book created for the student called Mefharet, is a good example in this regard:

"She has big blue eyes which are shiny, bright like the weather of spring over her thin and shiny face like a pink day leaf. But shades of curly, blonde eyelashes enter into her eyes and so it creates partly tempers, waves on that clear sky pieces. Gold-colored, little hair curls drop on her smooth, white forehead and a pair of thick, shiny braids hang on two sides of her white neck and her mouth seems like a rosebud and her teeth seem like two-row shiny pearls." [9].

Of course, all professions have some difficulties in their own way. Teaching profession is a profession containing a number of difficulties. Individuals who don't have certain qualifications such as patience, self-sacrifice, standing firm against difficulties, etc. can't achieve success in this 
profession. Teaching is one of the professions in which it is difficult even impossible to make up for a mistake.

Halide Nusret Zorlutuna sorrows and worries about a student, who wanted to go to teaching school and be a teacher, which she described "She was ornament woman who was born to spend a relaxed and delicate life wearing furs and emeralds like her eyes and pearls took color of her neck. In addition, such a soft compassion deepened into her eyes from time to time that it made me believe that she would be also a good "mother"." [9]. The reason is that student would spoil both herself and her students if she were a teacher. She encountered accidentally this student as the wife of a soldier and a mom after many years. She was happy since she wasn't mistake about her predictions and her student had a happiness becoming to her.

In this context, the following lines are important in the book telling how a teacher should be:

"You know, teaching - especially, primary school teaching- is a profession that requires endless toleration, endless renunciation and self-sacrifice. It is difficult to look after forty or fifty beautiful, ugly, clean, dirty, clever, stupid, peaceful and stubborn children and offer an insight into darkness of these little heads; everybody can't overcome it; but there are heroes created by God for this profession that they spend and can spend their life in this way!" [9].

"Halide Nusret thinks that her duty was being a teacher in those difficult days of the country. She believes that God created her to be teacher." [11]. As mentioned in the book, Halide Nusret, who remained separate from her school and students because of a serious illness but couldn't bear it much, left her son and husband in a different city and returned to her duty in order to come together her students. Although her illness continued, she came together her profession and students to which she was attached with a great passion. She talks about her relatives who say "What is wrong with you?... What's your problem?... What do you need?" as they can't understand why she doesn't care about herself and started to work again in such a difficult condition:

"Poor they, they can never understand "what I need". They measure the need by food, drinks, clothes... they measure it only by "money".

They don't know what it means to hold on to a purpose with "love" over all kind of benefits. They can't feel it is good, pretty good to die to do something. They are obliged to not feel this for life. I feel mercy for them inwardly; and I sometimes tolerate their foolish and heartless criticisms I heard thanks to this mercy. Sincere attentions and loves of "heads with caps", who were always in front of my door during my illness, were enough for me." [9].

It is actually take the easy way out to judge and evaluate students without questioning the reasons for their failures, naughtiness. A good teacher should be able to notice all economic, political, physical, mental obstacles for the academic success, and make effort to eliminate them. Zorlutuna taught under pretty negative conditions in the years when pains and effects of World War I and II were still new. She gave "poor children" a hug with a mother's compassion which they mostly had lost their fathers in the war and their mothers because of poverty and diseases in those troubled years. She trained them on one hand and tried to pick up the pieces for these little souls and bodies on the other hand.

Zorlutuna, in a section called "Irfan", learned about accidentally the facts of family of İfan called by other teachers as "abnormal child" and tried to reintroduce him to society as a healthy, educated individual. She tells about him as the following:

"Morose, bad-tempered, lazy, disgusting Irfan!..

Set this abnormal child aside!...

Yes, his teachers always told like that, we told like that!

We made cruel decisions, drew the long bow without knowing under which conditions that little child was, how he continued his unhappy life going worse day by day!

If an accident, -only an accident- didn't show me dry bread of Irfan, this poor child would be "bad-tempered, lazy and abnormal" for me until now. There is more. Of course Irfan would not pass the class that year and in next year... In brief, future of the child was actually in danger into our hands!" [9].

Zorlutuna experienced big miseries as well as the great pleasure by performing this profession. She tells her material and losses in her book as the following:

"Do you say "What about miseries?"...

Oh!.. Yes, miseries ... the greatest heartache felt after the "Losses"! I keep strictly in the foggiest sides of my mind what I lost in sense. But those who I buried are as fresh as a spring flower and as beautiful and clear as a light piece...

I never forget and can't forget them. Size by size, multi-colored, sparkling girls and boys from "Nadide" to "Semih"... Kadriye, Maide, Halime, Cavit, Shehvar, Fahri...My little poor children, each of them was a real value! [9].

It is an important subject that all teachers should address the students, which are considered as different values, with their names and try to make important contributions to establishment of self-confidence. Halide Nusret, by the importance attached to this issue, tries to address her "dear children" in her class with their names as well as nice words which she believes they will take a part in establishment of the future. Moreover, she gives names of 
her children called "my little friends" to most of the sections formed in the book. Nadide, Selim, Zeyno, İran and Osman are some of them.

Of course, people love being addressed with good words at all ages. It is also precondition of establishing a good and desired relationship between individuals. In this context, educators should be very careful of addressing the students and pay attention to use the salutations which can be loved and which make it easy to win their favor. It is required to pay attention to classes teaching basic principles of communication in educational institutions where teachers are trained.

Salutations used by the author while talking about the students in the book called "My Little Friends" show her love, respect and appreciation for them. In the book, we encounter the following pleasant salutations for the students which she believed they will be a light for future of this unlucky country into the darkness when we take pains with them: "My little friends, pure little children, my little, poor children, my buddy, kiddies, my kiddy, child, my child, my dear child, etc."

Author addresses a student called Zeynep as "Zeyno" with a term of affection, which she is called as "Arabian" due to her body color in the class. After that, other students set the old salutation aside and use title of "Zeyno" used by their teacher. This condition is involved in the book as the following:

"There were two students called Zeynep in class. One of them was a pink-white colored, blonde girl: 62 Zeynep Recep. The other one was a milk chocolate-colored girl with curly, black hair. She had thin, elegant, meaningful face.

Her friends called one of them as "Blonde Zeynep" and other girl as "Arabian!"

"Arabian!"

She was not angry with this salutation and always gave a response by smiling them.

Then, she dropped her head and with a hidden complaint in her voice, she said:

-It is not a lie, they tell the truth!

But she argued with her friends without a reason every day ...

I said "Zeyno" this girl -my Zeynep- to separate two students called Zeynep bin the class. After that day, "Arabian" was forgotten and everybody called her as "Zeyno". After being called like that, a velvet smile shined and then died into her black eyes with a deep pain" [9].

There are always several ways to transfer the knowledge in teaching profession. Teachers should be able to focus on success by several ways which they have to find one or more of the most proper learning methods for their students who are different worlds individually. Teaching profession is a profession that requires both personal and field information by its some properties. Teachers having these two competences in this profession have endless ways to achieve success. Zorlutuna tells how she encouraged and motivated her student called Osman, who was pretty weak in all classes, and made him achieve success:

"Any teacher was not pleasant with him. You can now imagine how he was in Turkish classes.

One day, I never forget, I was reading one of the poems of Behçet Kemal Çağlar in the class; my children were listening in silence and pleasure. Osman was listening with her half-open mouth, as usual.

I asked when I finished reading:

-Is it nice Osman?

He sighed and told as if he was in a dream:

"Very nice!" he said. "And you are reading very well teacher! Nobody can read like you!"

Come on! I said and smiled. Many of my students read better than me. Osman, I'm serious. If you make effort, you will read like me, maybe better than me....

He interrupted me and lost himself as it were:

Are you kidding me, forswear! Me, can I read like you?, he shouted.

And I easefully said:

Those who read not different from you, please try for one time. But you should read more. Do you understand? Read too much. For ten times, twenty times... without being bored! And listen to me while I teaching the lesson. Comprehend completely what I read means. You will see how easy it is, you will be surprised!

$\cdots$

I remember that I wrote the following ones under the homework of composition which I gave it back to him the day after:

"You see that there are mistakes in spelling, expressing and writing. You should correct it my child. You should be very careful and show great effort on this. If you study, I think you will definitely write well. You have the capability."

Don't be disappointed, study, I said. Study! Who studies wins one day. Repeat it always by yourself!

Who studies wins one day

Child repeats such as replication:

- Who studies wins one day.

Osman studied and won. 
For the second school report, he got "6" in Turkish and " 8 " for the third. Can you believe?

And all teachers are shocked which they say "This child can't be successful even though he studies in this class for three years!"

That year, Osman passed the class by a condition." [9].

The successes targeted in the education can't be reached only by teachers. Education is performed by opportunities offered by the government, competences of the teachers, families supporting their children in material and moral sense with the belief that education is necessary, and students who don't wasted the opportunities offered in this regard. A missing condition will hinder us from reaching the goal.

The author believes there is a need for parent-teacher association in education even tough for the conditions in first years of Foundation of the Republic and always tries to establish this system. She tries to consider conditions of their family while evaluating reasons for their success or failures of the students. She often visits the families after school, thinks of what can be done for needer students and their families and reaps the benefits of eliminating both a professional and social trouble. She explains her thoughts on this subject as the following:

"Even though I didn't work for school management excluding the first second years of my school life, it is my habit to get information on parents of the children nearly as much as, even more than my administrative colleagues. I always founded parents-teachers associations - of course, in a small scale- on my own for fifteen, twenty years now. I had more times to be satisfied since I lived voluntarily in rural areas for most of my teaching year." [9].

Zorlutuna, who taught in various schools for thirty three years, involved her memories and experiences in teaching in the novel called "Novel of A Period (Bir Devrin Romanl)" as well as "My Little Friends" [11, 12].

\section{Result and Suggestions}

In consequence, "My Little Friends" is a memory book by a woman teacher who wrote what she observed while performing this profession. These memories tell the struggle for education in several cities of Turkey in the first years of Republic despite all poverty and troubles, and a warm teacher-student relationship established by this teacher with her students. One of the most important properties of the book is that it shows problems teacher might encounter while performing the profession and acts as a guide in solving these problems. Accordingly, teachers should love students and make students love them, be fair for all students, guide them for good and bad, encourage them and they should not be afraid of any troubles, give up hope and should continue teach event the weakest student with patience, seek for new solutions in teaching, establish a relationship with students' parents to achieve success which they are one of the most important shareholders in the education, remember teaching is firstly self-sacrifice and most importantly they should be model for students in all respects. In this regard, "My Little Friends" is a highly valuable and useful resource that can be recommended in the relevant classes in order to make students understand how this occupation should be performed in the institutions where teachers are trained.

The work of Zorlutuna is parallel to the General Proficiency of Teaching Profession which is composed of the categories of Vocational Knowledge, Vocational Skills, Attitude and Values determined by the Ministry of National Education. In particular, the work expresses a distinct asset with the example of "National and Universal Values, Student Approach, Communication and Collaboration, Personal and Professional Development" competencies [20] in the Attitudes and Values category.

\section{REFERENCES}

[1] Fidan, N. \& Erden, M. (1987). Eğitim Bilimine Giriş̧. Ankara: Kadıoğlu Matbaası.

[2] Millı Eğitim Temel Kanunu. http://mevzuat.meb.gov.tr/html/temkanun_0/temel kanun_0.html [e.t. 15.02.2018].

[3] Çelikten, M., Şanal, M. \& Yeni, Y. (2005). "Öğretmenlik Mesleği ve Özellikleri”, Erciyes Üniversitesi Sosyal Bilimler Enstitüsü Dergisi, 19: 207-237.

[4] Övet, O. (2006). Eğitim Fakültesi Öğrencilerinin Ögretmenlik Mesleğini Tercih Etmelerinde Etkili Olan Faktörlerin Belirlenmesi. Yüksek Lisans Tezi. İstanbul: Yeditepe Üniversitesi Sosyal Bilimler Enstitüsü.

[5] Kılcan, B., Keçe, M., Çepni, O. \& Kııınç, A. Ç. (2014). "Prospective teachers' reasons for choosing teaching as a profession”. Kastamonu Ĕ̈itim Dergisi. 22 (1): 69-80.

[6] Çapanoğlu, M. S. (1964). Basın Tarihine Dair Bilgiler ve Hatıralar. İstanbul,

[7] Coşkun, B. (2010). Halide Nusret Zorlutuna (Hayatt-Eserleri-Fikirleri). Doktora Tezi. Marmara Üniversitesi Türkiyat Araştırmaları Enstitüsü.

[8] Gürel, Z. (1988). Hâlide Nusret Zorlutuna. Ankara: Kültür ve Turizm Bakanlığı Yay.

[9] Zorlutuna, H. N. (2009). Benim Küçük Dostlarım. Ankara: Timaş Yay.

[10] Tillman, D. (2014). 8-14 Yaş Grubu Öğrencileri için Yaşayan Değerler Eğitimi Etkinlikleri (Çeviri Editörü V. Aktepe). Ankara: Eğitim Kitabevi Yay.

[11] Erdal, K. (2005). Halide Edib Adivar ve Halide Nusret 
Zorlutuna'nın Eserlerinde Öğretmen ve Eğitim. Doktora Tezi. Uludağ Üniversitesi Sosyal Bilimler Enstitüsü.

[12] Zorlutuna, H. N. (1978). Bir Devrin Romanı. Ankara: Kültür Bakanlığı Yay.

[13] Yıldırım, A. \& Şimşek, H. (2006). Sosyal Bilimlerde Nitel Araştırma Yöntemleri (6. Bask1). Ankara: Seçkin.

[14] Karasar, N. (2010). Bilimsel Araştırma Yöntemi. (21. Bask1). Ankara: Nobel.

[15] Sanal, M. (2010). “Halide Edib Adıvar'ın (1884-1964) Öğretmenlik Mesleğinin Niteliğine İlişkin Görüssleri”. The Journal of International Social Research (Uluslararasl Sosyal Araştırmalar Dergisi). 3 (11): 528-538.

[16] Atıcı, E. S. \& Yaylı, D. 2011) "Çalıkuşu Romanındaki Öğretmen Metaforlarının İncelenmesi”. Uluslararası Türkçenin Eğitimi-Öğretimi Kurultayı 8-9 Eylül 2011
Sakarya.

[17] Y1lmaz, E. (2007). “Türk Edebiyatında Kadın Öğretmen Tiplemeleri”. Sakarya Üniversitesi, Eğitim Fakültesi Dergisi. 14: 240-251.

[18] Aydın, Y. (2006). Reşat Nuri Güntekin'in Çalıkuşu, Acımak, Yeşil Gece, Kan Davası Romanlarında Öğretmen Tipleri ve Toplumun Öğretmen Algılaması. Yüksek Lisans Tezi. Erzurum: Atatürk Üniversitesi Sosyal Bilimler Enstitüsü.

[19] Emek, M. (2010). "Hikâye Türündeki Metinlerde Yer Alan Türkçe veya Edebiyat Öğretmeni Karakterinin İlköğretim Programındaki Eğitim Değerleri Bakımından İncelenmesi”. Türklük Bilimi Araştırmaları. 27: 297-319.

[20] https://oygm.meb.gov.tr/meb iys dosyalar/2017 12/11115 355_YYRETMENLYK_MESEEYYY_GENEL_ȲETERLY KLERY.pdf
* This study has been presented in the II. International Research Congress on Social Sciences held in Baku Azerbaijan 19-21 October, 2017. 